\title{
Corpus-Based Analysis of Ideological Bias
}

Corpus-Based Analysis of Ideological Bias presents research combining a range of corpus-linguistic techniques which are employed to analyse how migration discourse is (re)constructed in the contemporary British press. Two specialised corpora containing 1,000 news reports, editorials, and opinion pieces from five major national British newspapers were collected and annotated for this research. The event separating these two corpora is the 2016 referendum on Britain's membership of the European Union (EU). In its analysis, this book:

- employs both quantitative and qualitative analytical methods, with four case studies offering a broad perspective on how the topical socio-political issues of migration and asylum seeking are represented by left- and right-wing British newspapers;

- $\quad$ explores how newspapers reveal their political orientation and promote their political agenda by employing specific linguistic patterns and discursive strategies - in this case, in the representation of the key social actors within migration discourse;

- provides case studies that place a particular focus on the discourses surrounding European migrants and migration within the EU, which proved to be a very popular topic in the British press both before and after the 2016 EU membership referendum; and

- offers a comparative corpus analysis that seeks to ascertain whether media discourse regarding EU migration has changed in the wake of the referendum.

This book is a useful source not only for students of English, linguistics, and media studies but also for researchers in the fields of applied corpus linguistics, critical discourse studies, contemporary media analysis, and metaphor research.

Anna Islentyeva is a research associate and senior lecturer in sociolinguistics in the Department of English Language and Literature at the Freie Universität Berlin, Germany. Her scientific interests include semantics, conceptual metaphor, discourse analysis, and critical discourse studies. Anna is interested in research that places a special emphasis on the social aspects of language and examines ideologically relevant linguistic patterns in different types of discourses. Her current research projects address media discourses surrounding European migration following the EU referendum, as well as representations of Europe and Britain in the British media. Her recent publications include The Europe of Scary Metaphors (2019) and The Undesirable Migrant in the British Press (2018). 


\section{Routledge Applied Corpus Linguistics}

Series Editor: Michael McCarthy and Anne O'Keeffe

Series Co-Founder: Ronald Carter

Editorial Panel: IVACS

Michael McCarthy is Emeritus Professor of Applied Linguistics at the University of Nottingham, UK, Adjunct Professor of Applied Linguistics at the University of Limerick, Ireland and Visiting Professor in Applied Linguistics at Newcastle University, UK. He is co-editor of the Routledge Handbook of Corpus Linguistics, editor of the Routledge Domains of Discourse series and co-editor of the Routledge Corpus Linguistics Guides series.

Anne O'Keeffe is Senior Lecturer in Applied Linguistics and Director of the InterVarietal Applied Corpus Studies (IVACS) Research Centre at Mary Immaculate College, University of Limerick, Ireland. She is co-editor of the Routledge Handbook of Corpus Linguistics and co-editor of the Routledge Corpus Linguistics Guides series.

Ronald Carter (1947-2018) was Research Professor of Modern English Language in the School of English at the University of Nottingham, UK. He was also the co-editor of the Routledge Corpus Linguistics Guides series, Routledge Introductions to Applied Linguistics series and Routledge English Language Introductions series.

IVACS (Inter-Varietal Applied Corpus Studies Group), based at Mary Immaculate College, University of Limerick, is an international research network linking corpus linguistic researchers interested in exploring and comparing language in different contexts of use.

The Routledge Applied Corpus Linguistics Series is a series of monograph studies exhibiting cutting-edge research in the field of corpus linguistics and its applications to real-world language problems. Corpus linguistics is one of the most dynamic and rapidly developing areas in the field of language studies, and it is difficult to see a future for empirical language research where results are not replicable by reference to corpus data. This series showcases the latest research in the field of applied language studies where corpus findings are at the forefront, introducing new and unique methodologies and applications which open up new avenues for research.

Other titles in this series

\section{Interdisciplinary Research Discourse}

Corpus Investigations into Environment Journals

Paul Thompson and Susan Hunston

Native and Non-Native Teacher Talk in the EFL Classroom

A Corpus-informed Study

Eric Nicaise

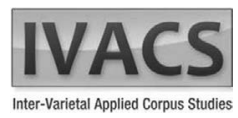

For more information about this series, please visit: www.routledge.com/series/ RACL 


\section{Corpus-Based Analysis of Ideological Bias}

Migration in the British Press

\section{Anna Islentyeva}

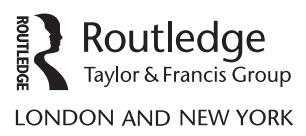


First published 2021

by Routledge

2 Park Square, Milton Park, Abingdon, Oxon OX14 4RN

and by Routledge

52 Vanderbilt Avenue, New York, NY 10017

Routledge is an imprint of the Taylor \& Francis Group, an informa business

(C) 2021 Anna Islentyeva

The right of Anna Islentyeva to be identified as author of this work has been asserted by her in accordance with sections 77 and 78 of the Copyright, Designs and Patents Act 1988.

All rights reserved. No part of this book may be reprinted or reproduced or utilised in any form or by any electronic, mechanical, or other means, now known or hereafter invented, including photocopying and recording, or in any information storage or retrieval system, without permission in writing from the publishers.

Trademark notice: Product or corporate names may be trademarks or registered trademarks, and are used only for identification and explanation without intent to infringe.

\section{British Library Cataloguing-in-Publication Data}

A catalogue record for this book is available from the British Library

Library of Congress Cataloging-in-Publication Data

Names: Islentyeva, Anna, author.

Title: Corpus-based analysis of ideological bias : migration in the British press / Anna Islentyeva.

Description: London ; New York : Routledge, 2020. | Series: Routledge applied corpus linguistics | Includes bibliographical references and index.

Identifiers: LCCN 2020022121 (print) | LCCN 2020022122 (ebook) | ISBN 9780367207168 (hardback) | ISBN 9780429263064 (ebook)

Subjects: LCSH: Journalism—Objectivity—Great Britain-History21 st century. | Journalism - Great Britain - Language. | Emigration and immigration-Press coverage - Great Britain - Case studies. | Corpora (Linguistics) $\mid$ Discourse analysis-Political aspects-Great Britain.

Classification: LCC PN5124.O24 I85 2020 (print) | LCC PN5124.O24 (ebook) | DDC 070.4/49304841—dc23

LC record available at https://lccn.loc.gov/2020022121

LC ebook record available at https://lcen.loc.gov/2020022122

ISBN: 978-0-367-20716-8 (hbk)

ISBN: 978-0-429-26306-4 (ebk)

Typeset in Times New Roman

by Apex CoVantage, LLC 


\section{Contents}

List of figures viii

List of tables $\quad$ ix

Acknowledgements $\quad$ xi

Introduction: language corpora and media discourse on migration

The scope of research 1

European migration and asylum seeking: how the problem

is constructed in the press 2

Major research goals and research methods 5

Structure of the book 6

1 Ideology in the contemporary media: bias in the British press

1.1 Approaches to discourse and key goals in critical discourse analysis 10

1.2 Media discourse as an instrument of power 17

1.3 The British press: political allegiances and ideological interests 20

1.4 Summary: discourse as a form of social practice 26

2 Corpus-based discourse analysis: data collection and corpus construction

2.1 Central principles in the study of language 29

2.2 Corpus linguistics as a methodology 32

2.3 Data collection, types of corpora, and newspaper corpora 37

2.4 Corpus linguistics techniques 44

2.5 Advantages of combining critical discourse analysis and corpus linguistics 47 
vi Contents

3 Discursive representations of refugees, asylum seekers, immigrants, and migrants (RASIM) prior to the

EU referendum

3.1 Introducing RASIM in media discourse 53

3.2 Quantitative analysis: frequency analysis and quantification techniques 54

3.3 Collocational analysis and typical contextual domains 59

3.4 Discursive representations of EU migrants in the British press 65

3.5 Asylum seekers and refugees 77

3.6 Summary: ideological differences in the use of RASIM terms 86

4 Discursive representations of migrants after the EU referendum

4.1 The EU membership referendum: political and media discourse 90

4.2 Quantitative analysis of the post-referendum corpus: shifting the focus 91

4.3 Collocational analysis and salient contextual domains 96

4.4 Discursive representations of EU migrants in the British press 103

4.5 Summary: the transformation of media discourse surrounding EU migration 112

5 The English garden: a metaphor for English society

5.1 The English garden metaphor and English national identity 115

5.2 The Telegraph editorial: the conservative ideal of a hierarchical society 116

5.3 Literary and cultural allusions and visual analysis 124

5.4 The Guardian opinion piece: subverting the English garden metaphor 128

5.5 Summary: the ideological basis of the English garden 132

6 The metaphorical motif of war in the British press

6.1 The semantics of war: the core sense of war and its definition 135

6.2 The semantic prosody of war and the construction of the metaphorical motif 141 
6.3 The war motif in the British press: a quantitative analysis 145

6.4 Analysis of articles from left-wing newspapers 152

6.5 Analysis of articles from right-wing newspapers 156

6.6 Summary: politics is war 161

Conclusion: principles of cohesion and evaluation in newspaper texts

Theoretical and methodological implications 164

Major findings and results of the corpus-based studies 167

Outlook and further research 169

Appendix

Multi-cultivars 174

A passport to my lovely garden? Dream on, you

wretched souls 174

Index 


\section{Figures}

3.1 Distribution of migrant( $(s)$ and immigrant $(s)$ in the

Pre-Referendum Corpus

3.2 Distribution of REFUGEE and ASYLUM SEEKER in the Pre-Referendum Corpus

4.1 Distribution of MIGRANT in the Pre- and Post-Referendum Corpora

4.2 Distribution of IMMIGRANT in the Pre- and Post-Referendum Corpora

4.3 Distribution of REFUGEE in the Pre- and

Post-Referendum Corpora

5.1 Illustration by David Foldvari from The Guardian

6.1 Distribution of the lemmas from the source domain of WAR in the Pre-Referendum Corpus 


\section{Tables}

1.1 Newspaper support for political parties in the UK general elections

1.2 Daily circulation figures for British national newspapers in 2013 and 2014

1.3 Daily circulation figures for British national newspapers in 2016 and 2018

1.4 Average monthly print and digital readership for November 2018 (in 1,000 copies)

2.1 Basic types of corpus annotation

2.2 Number of text types in each subcorpus of the Pre-Referendum Corpus (2013-2014)

2.3 Number of text types in each subcorpus of the Post-Referendum Corpus (2016-2018)

2.4 Total number of tokens in each subcorpus 42

2.5 Metadata for the Pre-Referendum Corpus $\quad 44$

2.6 Metadata for the Post-Referendum Corpus 44

3.1 Raw frequencies of RASIM terms in the Pre-Referendum Corpus (2013-2014)

3.2 Normalised frequencies of RASIM terms per 10,000 tokens in the Pre-Referendum Corpus

3.3 Left-hand collocates attracted to MIGRANT in the Pre-Referendum Corpus

3.4 Left-hand collocates attracted to IMMIGRANT in the Pre-Referendum Corpus

3.5 Right-hand collocates attracted to MIGRANT in the Pre-Referendum Corpus

3.6 Right-hand collocates attracted to IMMIGRANT in the Pre-Referendum Corpus

3.7 Corpus-based definitions of immigrant and migrant

3.8 KWIC concordance for the construction adjective $+E U$ migrants in the Pre-Referendum Corpus

3.9 Most frequent nouns appearing in the construction noun + of MIGRANT 
3.10 KWIC concordance for the collocation Romanian and/or Bulgarian migrants

3.11 Left-hand collocates attracted to REFUGEE in the Pre-Referendum Corpus

3.12 Left-hand collocates attracted to ASYLUM SEEKER in the Pre-Referendum Corpus

4.1 Raw frequencies of RASIM terms in the Post-Referendum Corpus (2016-2018)

4.2 Normalised frequencies of RASIM terms per 10,000 tokens in the Post-Referendum Corpus

4.3 Normalised frequencies of RASIM terms per 10,000 tokens in the Pre-Referendum Corpus (2013-2014)

4.4 Most frequent left-hand collocates of MIGRANT in the Pre- and Post-Referendum Corpora

4.5 Left-hand collocates attracted to MIGRANT in the Post-Referendum Corpus (2016-2018)

4.6 Left-hand collocates attracted to MIGRANT in the Pre-Referendum Corpus (2013-2014)

4.7 Most frequent left-hand collocates of IMMIGRANT in the Pre- and Post-Referendum Corpora

4.8 KWIC concordance for the construction adjective + EU migrants in the Post-Referendum Corpus

4.9 Most frequent nouns appearing in the construction (high)-skilled + noun in the Post-Referendum Corpus

4.10 Most frequent noun collocates of $E U$ in the Post-Referendum Corpus

4.11 Right-hand collocates attracted to $E U$ in the left-wing subcorpus of the Post-Referendum Corpus

4.12 Right-hand collocates attracted to $E U$ in the right-wing subcorpus of the Post-Referendum Corpus

6.1 Corpus-based definition of the word war

6.2 KWIC concordance for the collocation war damage from the BNC (1994)

6.3 KWIC concordance for the collocation war damage from the COCA (2008)

6.4 Absolute frequencies of the lemmas from the source domain of WAR in the Pre-Referendum Corpus (2013-2014)

6.5 Observed and expected frequencies of the wAR metaphor employed by the left- and right-wing press in the Pre-Referendum Corpus (2013-2014) 


\section{Acknowledgements}

This book is the result of a five-year period of research that has been full of new, exciting experiences and interesting discoveries. I would like to thank my colleagues and students in the Department of English Language and Literature at the Freie Universität Berlin, as well as my family and close friends who have supported me over the years.

I am particularly grateful to Igor Tolochin from St Petersburg State University, who introduced me to English semantics and the British National Corpus during my time there as a BA student. Professor Tolochin has been my academic supervisor and constant supporter for the past 12 years.

I would like to acknowledge the unfaltering encouragement of Anatol Stefanowitsch from the Freie Universität Berlin, who stimulated my profound interest in corpus linguistics and the cognitive approach to metaphor analysis. I thank Professor Stefanowitsch for his help in annotating the British newspaper corpora that I use for the research featured in this book. I also owe a great deal to my student assistants, Mihera Abdel Kafi, Torben Scheffler, and Willi Werner, who helped me gather corpus data for the Post-Referendum Corpus.

To the thoughtful, engaged students who took part in my Discourse Analysis: Ideology and Identity seminars in 2018 and 2019: thank you for your stimulating discussions and vital insights on the English garden metaphor featured in Chapter 5 of this book.

Very special thanks to my student and friend Louise Pain for her invaluable comments on the previous versions of the manuscript.

I would like to acknowledge the constant support and assistance of the Routledge editors for the Applied Corpus Linguistics Series, Anne O'Keeffe and Michael McCarthy, as well as the editorial assistants for English Language and Linguistics, Elizabeth Cox and Adam Woods.

Above all else, I thank my family. I dedicate this work to my parents, Marina Islentyeva and Vladimir Islentyev, who made it possible for me to study and carry out my research in Berlin. I thank them for their love and support throughout my life, especially during the period in which I worked on this book. 
To my parents 


\section{Introduction}

\section{Language corpora and media discourse on migration}

\section{The scope of research}

The study of language use in the news media has come to be of central importance to a broad range of academic disciplines including media and communication studies, political studies, sociology, and linguistics. The increasing relevance of media language analysis can be explained by the omnipresence of the news media. The mass media serves as one of the primary and ostensibly most trustworthy sources of information for the public, even in this era marked by the increasing popularity of social networks. Furthermore, the media acts as a lens that is able to focus on specific issues while defocusing others, thus producing dominant discourses and constructing the identities of different social actors.

In social studies, there is an increasing demand for applied research that requires more empirically oriented discourse-analytical studies. This book represents a corpus-based linguistic analysis of the modern migration discourse produced by the British national press. The analysis combines methods developed in cognitive linguistics, specifically Conceptual Metaphor Theory (CMT) with Critical Discourse Analysis (CDA). Each of these approaches offers a diverse set of tools for analysing the evaluative nature of meaning in newspaper texts; in combination, they provide a solid framework for interpreting ideological bias on both a structural and semantic level.

In contemporary linguistics, it is sometimes assumed that discourse-analytical methods are incompatible with corpus linguistics - the former applied to the study of individual texts (Lee 2008) and employed in the critical investigation of socio-political themes, and the latter chiefly focuses on the study of large bodies of electronically stored texts and is designed to facilitate searches for specific lexical and grammatical patterns (Baker et al. 2008: 273-276). This assumption is rather misleading (cf. Taylor \& Marchi 2018); the use of corpora is rapidly becoming an integral part of linguistic analysis. Although the combination of corpus-linguistic methods with CDA is not a new practice, the overall number of such studies is rather low compared to the number of studies in corpus linguistics or CDA alone (Baker et al. 2008: 274). This book focuses on migration - one of the recurrent themes in the contemporary media - and seeks to fill the aforementioned methodological gap by providing a multi-level, corpus-based discourse analysis of 1,000 articles from 


\section{Introduction}

five British national newspapers, thereby revealing how these two approaches to the study of media discourse can be interrelated and combined in various ways.

It should be emphasised that corpus linguistics is seen not as a branch of linguistics, but rather as a set of practices and methods. More broadly speaking, it is an approach to the study of language (Lee 2008: 87; McEnery \& Hardie 2012: 6, 147), making corpus-based linguistics a more accurate term to use. Linguists who use corpora are just as interested as other linguists in key aspects of language like semantics, syntax, morphology, and language change (Lee 2008: 87). However, corpus linguists aim to achieve more systematic ways of studying language, one of which involves employing large collections of computerised texts and statistical methods. Indeed, the term corpus-based approach is used widely in corpus linguistics. McEnery \& Hardie (2012: 6) refer to the differences between corpus-based and corpus-driven approaches, explaining that corpus-based studies employ corpora to explore a theory or hypothesis, whereas corpus-driven linguistics (Sinclair 1991, 2004; Tognini-Bonelli 2001) uses the corpus itself as the sole source of hypotheses about language. Linguists working within the corpus-based approach define corpus linguistics as a method. The difference between corpus-based and corpus-driven approaches is discussed in more detail in Section 2.2, and Section 2.5 introduces some other methodologies that combine discourse analysis and corpora.

Media discourse on migration is the focus of the research presented in this book. The term discourse - as a complex concept - is understood in various ways within the academic cultures of different countries. Generally, a distinction can be drawn between the theoretical approach to discourse which originated in France and the tradition of empirically oriented discourse research that was developed in the UK and the USA (Angermuller et al. 2014: 2). Chapter 1 will elaborate on a number of approaches to discourse analysis and outline the key objectives of CDA.

It is widely acknowledged that the contemporary mass media is central to the construction of discourses and the promotion of ideologies and value systems. The media is able to focus on particular issues while recontextualising others. The general public uses this mediated information as a source of knowledge about world events, and the mass media plays a pivotal role in terms of shaping public opinion. As a rule, the public does not always have direct access to primary texts such as governmental or parliamentary reports. Consequently, most primary texts and the values they promote are mediated via secondary sources such as news reports, editorials, opinion pieces, and other forms of media. Secondary texts act as a lens through which primary texts are reified, but may also be recontextualised (Koller 2004: 45). The central research question of this book involves how newspapers with specific political orientations apply various linguistic patterns and structures in their reporting in order to promote their political agendas.

\section{European migration and asylum seeking: how the problem is constructed in the press}

Immigration is a highly topical socio-political issue and the major theme that unites the 1,000 newspaper articles that were collected and annotated for this research. 
These articles make up two newspaper corpora: one that contains 500 articles from the years 2013 to 2014, and another that contains 500 articles from the years 2016 to 2018. The event separating these two corpora is the referendum on British membership of the European Union (EU), held in the UK on 23 June 2016. Throughout this book, these two collections of newspaper articles will be referred to as the PreReferendum Corpus and the Post-Referendum Corpus, respectively.

Immigration and asylum seeking are among the most topical issues discussed in the British media, and, as such, attract a great deal of public attention in contemporary Britain. Hart (2010: xii; emphasis added) notes: "Immigration remains a contentious issue in the UK and one which is largely fuelled by the media". Between 2005 and 2020, a number of bills restricting immigration and the right to seek asylum were passed before the UK parliament: The Immigration, Asylum and Nationality Act 2006; UK Borders Act 2007; and the Borders, Citizenship and Immigration Act 2009, among others. Moreover, immigration became one of the central issues in the 2005 general election campaigns of the political right (Charteris-Black 2006), while the 2010 and 2015 election campaigns of both the Conservative and Labour parties were centred around the issue of European migration. This issue was so pivotal, in fact, that the then prime minister and leader of the Conservative Party, David Cameron, made an election promise to hold an EU membership referendum.

Migration within the European Union (EU) and the UK-EU relationship are two topics that have attracted a great deal of public and media attention in Britain in the past 15 years. 2004 saw the most significant expansion of the EU in its history in terms of territory and population, with five Central and Eastern European countries (Czech Republic, Hungary, Poland, Slovakia, and Slovenia), three Baltic States (Estonia, Latvia, and Lithuania) - collectively referred to as A8 countries or the EU8 - and two Mediterranean countries (Malta and Cyprus) joining the Union in that year (cf. Leonard \& Taylor 2016). Free movement of people is one of the four freedoms of the EU, along with free movement of goods, services, and capital, and would naturally have applied to these countries, but due to concerns about migration from the newly acceded countries to the older EU states (EU15), some transitional restrictions were put in place for five years until 2011. Romania and Bulgaria joined the EU in 2007 as part of the so-called "Eastern enlargement". Once again, the UK, along with a number of other EU states, imposed transitional employment restrictions on Romanian and Bulgarian workers - restrictions that were not lifted until 2014. The Pre-Referendum Corpus contains articles that focus on the end of these restrictions on Bulgarians and Romanians in January 2014. The enlargement of the Union and the increased mobility of its citizens within its member states made European migration to Britain one of the most hotly debated issues in the British media.

The mobility of EU citizens within the Union inevitably raised questions not only of national identity (Bayley \& Williams 2012), but also of British exceptionalism, a concept that stands in opposition to the notion of a united Europe. Spiering (2015: 2) describes the UK-EU relationship as a continuously troubled one "marked by party divisions, media hostility, opt-outs and opt-ins, and persistent calls for an 


\section{Introduction}

in-out referendum". This troubled relationship is deeply rooted in a perceived cultural division between two opposing entities. Spiering (2015: 3-5) points out that we are dealing here not with an essential quality of Britishness, but rather with a perception or a constructed idea of extra-Europeanness that is not eternal or innate; instead, the relationship is determined by strong cultural notions of differentness. The Britain versus Europe dichotomy is additionally complicated by the fact that different nations, the English, the Welsh, the Scottish, and the Irish, inhabit the British Isles, making them a multination state. In a way, Britain can be seen as a cultural unit: the nations that inhabit these isles have a shared history, a shared language, and shared values, but, on the other hand, being English or Scottish is not equivalent to being British. According to Braber's study (2009: 307), some Scottish people, for example Glaswegians, do not feel that "a sense of Britishness forms a strong part of their identity as [it] has English connotations" (emphasis added). Evidently, national identities are not fixed entities, but are relational concepts (Braber 2009: 308). Spiering (2015: 6) also asserts that national identities are relational; in order to define who we are, we need to distinguish ourselves from others. In their quest to forge their own unique identity, the English tend to define themselves against the Scots, the Welsh, and the Irish, and often claim to hold a special position within Britain. Immigrants and other ethnic and religious minorities represent another big out-group, followed by mainland Europeans, who function as "significant others in the English quest for the national self" (Spiering 2015: 6).

The labels English and British are often used interchangeably (cf. Spiering 2015: 4). In many cases, this is a conscious ideological decision made by an author who does not wish to maintain a clear distinction between the two groups. As mentioned previously, the English often claim to have a special position within Britain, which is why English is often used in a broader sense to denote or represent a certain cultural tradition that primarily exists in the form of the English Language, the Queen of England, English breakfast tea, English weather, and the English rose. In this context, Englishness is the essence of Britishness at the level of stereotypes. The pair English/British represents an element of the socio-historical tradition; a dichotomy that will be discussed in more detail in Chapter 5 with an exploration of the English garden as a cultural construct and ideological metaphorical motif. Building on questions of national identity and the constructed dichotomy British versus European, Chapters 3 and 4 will analyse media representations of Europeans, in particular EU migrants in the UK.

Finally, it was not only EU migration to the UK that gained public and media attention between 2013 and 2018. The growing number of people arriving in the EU from across the Mediterranean Sea raised serious concerns both in Europe and Britain. Ongoing armed conflicts in Afghanistan, Iraq, and Syria; human rights violations; and unstable political climates and social problems, along with environmental issues, have led to the constant movement of people and, as a result, to a growing number of forcibly displaced people, identified as asylum seekers and refugees. Since 2011, the number of asylum seekers and refugees worldwide has increased by 40 per cent. According to the United Nations High Commissioner 
for Refugees (UNHCR), by the end of 2016, this number reached 65.6 million worldwide, which is the highest number since the Second World War. In 2016, which is often seen as the peak of the refugee crisis, the asylum seekers in the EU originating from Syria, Afghanistan, and Iraq constituted 50 per cent of the total number of those who applied for asylum in the EU.

The asylum issue, which is generally treated as part of a wider immigration issue, raises fundamental questions regarding the obligations that nation states have to non-citizens (Schuster 2003: 2). Those who claim to be refugees, but who have not yet been recognised as such, are referred to as asylum seekers (Schuster 2003: 3). It should be emphasised that in both political discourse and the media, it is often assumed that a group of asylum seekers consists of a very small sub-group of "genuine" asylum seekers - those who will ultimately be recognised as refugees. The rest of the group is thus considered to consist of a much larger contingent of "bogus" asylum seekers, who are referred to as economic migrants wishing to migrate, settle, and work in the host state (ibid.). Furthermore, much of the contemporary media and political discourse treats all asylum seekers as economic migrants in disguise and, as such, as a threat to the nation state that would receive them. As a result, European states try to filter economic migrants through the asylum process by using a definition of refugees that distinguishes between political and economic motives for flight (ibid.). However, distinctions between political and economic causes of migration, as well as differences between voluntary and involuntary migration, are difficult to ascertain. The linguistic analysis of the authentic data presented in this book aims to reveal the discursive ways these groups are presented in the contemporary British press.

\section{Major research goals and research methods}

Issues such as national sovereignty, immigration, free movement within the EU, border control, security, and the increasing number of asylum seekers, as well as the idea of national identity and British exceptionalism, all contributed to the decision to hold the EU membership referendum in 2016, which led to the UK's withdrawal from the EU - commonly known as Brexit. The linguistic analysis of the two newspaper corpora featured in this book aims to trace the correspondence between these complex socio-political events and the media's construction of the identities of the key social actors within migration discourse. This analysis pursues three key objectives in particular:

1 In Chapter 3, the focus is placed on the linguistic differences and similarities in the discursive representation of refugees, asylum seekers, immigrants, and migrants (RASIM) by left- and right-wing broadsheets and tabloids in years 2013 to 2014, on the threshold of the general election of 2015 and the EU membership referendum of 2016. The term RASIM was first introduced in Baker (2007) and later applied in Gabrielatos \& Baker (2008), Baker et al. (2008), Taylor (2014), Islentyeva (2018) and others. From a linguistic perspective, 
words pairs such as refugee-asylum seeker and migrant-immigrant are semantically related; there are, however, some subtle differences in their meaning that can be identified by means of a systematic corpus analysis.

2 Chapter 4 traces the transformation of migration discourse between 2016 and 2018, following the EU membership referendum. The focus is placed on the representation of European migrants, as the analysis aims to identify shifts in the representation of Europeans after the decision was made to leave to the EU.

3 Chapters 5 and 6 analyse recurrent metaphorical motifs that are employed in migration discourse, with a particular focus on their evaluative and ideological functions.

A multi-method approach that includes two types of language data analysis quantitative and qualitative - is employed in the case studies outlined in this book. In its broadest sense, the quantitative analysis of the newspaper corpora includes concordance and collocational/collexeme analyses, the extraction of ideologically relevant grammatical and metaphorical patterns from the corpora, as well as a statistical analysis that shows to what extent the findings are significant. The qualitative analysis involves contextual and intertextual analyses of the newspaper articles and serves as a further step in identifying the discursive strategies that are responsible for producing and reproducing ideology within a narrative. The ultimate goal of this book is to identify a set of systematic linguistic principles in the construction of dominant discourses, thereby revealing the nature of meaning in ideologically charged discourses on migration and asylum seeking by combining corpus linguistics with CDA. The case studies presented in this book aim to demonstrate how corpus techniques and discourse-analytical methods can contribute to a deeper understanding of the ideological processes at work.

\section{Structure of the book}

Chapter 1 introduces different approaches to discourse analysis, with a special focus on the key goals of Critical Discourse Analysis (CDA) and critical discourse studies (van Dijk 1995, 2015). In CDA, discourse is primarily seen as a form of social practice (Fairclough 2015), while the socio-political order is largely (re)constructed through a range of discursive practices that are capable of shaping the attitudes and points of view of the general public. Chapter 1 elaborates on the concepts of ideology and power in line with CDA, establishing a vital link between power relations, language in general, and discursive practices within different genres of writing. Mass media is of great interest for critical investigation as it constitutes one of the public's primary sources of information. Chapter 1 focuses on the contemporary British print media and provides a brief historical overview of the five newspapers - namely The Sun, The Daily Mail, The Daily Telegraph, The Daily Mirror, and The Guardian. The articles from these newspapers serve as data for the corpora employed in the case studies featured in this book. A special focus is given to the newspapers' political allegiances and the concept of ideological bias. 
Chapter 2 introduces the fundamental principles of modern language study, with a focus on the systematicity of analysis and frequency of occurrence as the two basic principles of corpus-based research (McEnery \& Wilson 2001), and provides a brief overview of corpus annotation. Section 2.2 defines the key criteria involved in constructing a balanced language corpus and lists the general corpora that are employed as reference corpora in this research. Section 2.3 provides a detailed overview of the process involved in designing and constructing the two comparable newspaper corpora analysed in this book. Finally, Chapter 2 elaborates on key corpus techniques, such as concordance and collocation analysis, and illustrates the advantages of employing a mixed-method approach that combines CDA and corpus linguistics when studying discourses (Baker 2006; Baker et al. 2008; Taylor \& Marchi 2018).

Chapter 3 focuses on media representations of refugees, asylum seekers, immigrants, and migrants (RASIM) in the period from 2013 to 2015, referred to as the pre-referendum period in the book. Frequency, concordance and collocational analyses help to identify the linguistic differences and similarities in the representation of RASIM by different British press outlets. The high frequency of the word migrant $(s)$ indicates that European migrants were a main focus of attention in the British press prior to the 2016 EU membership referendum. Chapter 3 demonstrates how a systematic application of corpus linguistic methods can assist in identifying recurrent patterns that are employed in the representation of RASIM, with a focus on the differences between how left- and right-wing newspapers employ these words.

Chapter 4 compares the linguistic patterns and discursive strategies identified in Chapter 3 with the patterns employed in the post-referendum period (2016-2018) in order to ascertain whether media discourse regarding EU migration has changed in the wake of the $2016 \mathrm{EU}$ membership referendum. In particular, the analysis aims to trace the differences and similarities between the representation of European migrants and migration within the EU after the 2016 referendum and compare these representations with the discourses constructed around EU migrants in 2013 and 2014. The comparative analysis thus brings to light the linguistic mechanisms that ensure that the ideologies promoted by different newspapers remain adaptable to the changing socio-political environment of contemporary Britain.

Chapter 5 represents a qualitative corpus-assisted analysis of two newspaper articles from The Daily Telegraph and The Guardian, both of which employ the English garden metaphor in their discussion of immigration and asylum seeking in the UK. The analysis identifies the different ways in which left- and rightwing newspapers use figurative language to discuss this complex socio-political issue. Chapter 5 also demonstrates the advantages of employing an approach that combines close reading with intertextual analyses (for example, referring to Rudyard Kipling's (1911) poem The Glory of the Garden and Jonathan Swift's (1729) Modest Proposal) and visual analyses (examining the accompanying photographs and illustrations). Chapter 5 concludes that the metaphor of the English garden is a politically charged figurative tool that represents the conservative ideal of a hierarchical society based on predominant values from Britain's imperial past. 
Chapter 6 shifts the focus from the representation of social actors (Chapters 3 and 4) and society (Chapter 5) to the representation of the political processes in the British press. The recurring use of words like attack, battle, defend, enemy, and fight in reference to politics suggests that the semantic domain of WAR is systematically transferred onto the domain of POLITICS. The focus of the analysis is the evaluative function of metaphor (Charteris-Black 2004), which shows how the ideologically charged motif POLITICS IS WAR is employed in the representation of different political positions. In terms of methodology, Chapter 6 employs both qualitative and quantitative techniques. The latter includes identifying metaphors employed in the Pre-Referendum Corpus (2013-2014), subsequently extracting relevant words from the corpus and assessing whether these words are used metaphorically in the target domain. The quantitative analysis is complemented by a close reading of a selection of articles from the respective newspaper corpus.

The conclusion explains that the research presented in this book goes beyond a mere linguistic analysis in that it focuses on the complex relationship between language, the media, and politics in terms how meanings and identities are constructed in contemporary Britain. The conclusion provides an overview of the key findings, explains their significance for linguistic research, and highlights methodological innovations. The benefits of combing corpus-linguistic techniques and discourse-analytical methods are outlined in terms of how this mixed-method approach can help clarify the semantics of RASIM terms, as well as contribute to critical research on contemporary media discourse.

\section{References}

Angermuller, Johannes, Dominique Maingueneau \& Ruth Wodak (eds.). 2014. The Discourse Studies Reader: Main Currents in Theory and Analysis. Philadelphia \& Amsterdam: John Benjamins.

Baker, Paul. 2006. Using Corpora in Discourse Analysis. London \& New York: Continuum. Baker, Paul. 2007. Discourses of Refugees and Asylum Seekers in the UK Press, 1996-2006: Full Research Report. ESRC End of Award Report, RES-000-22-1381. Swindon: ESRC.

Baker, Paul, Costas Gabrielatos, Majid Khosravinik, Michal Krzyzanowski, Tony McEnery \& Ruth Wodak. 2008. A Useful Methodological Synergy? Combining Critical Discourse Analysis and Corpus Linguistics to Examine Discourses of Refugees and Asylum Seekers in the UK Press. Discourse and Society, 19 (3), 273-306.

Bayley, Paul \& Geoffrey Williams (eds.). 2012. European Identity: What the Media Say. Oxford: Oxford University Press.

Braber, Natalia. 2009. I'm Not a Fanatic Scot, But I Love Glasgow: Concepts of Local and National Identity in Glasgow. Identity: An International Journal of Theory and Research, 9 (4), 307-322.

Charteris-Black, Jonathan. 2004. Corpus Approaches to Critical Metaphor Analysis. Basingstoke: Palgrave Macmillan.

Charteris-Black, Jonathan. 2006. Britain as a Container: Immigration Metaphors in the 2005 Election Campaign. Discourse and Society, 17 (6), 563-582.

Fairclough, Norman. 2015. Language and Power. 3rd ed. London \& New York: Routledge. 
Gabrielatos, Costas \& Paul Baker. 2008. Fleeing, Sneaking, Flooding: A Corpus Analysis of Discursive Constructions of Refugees and Asylum Seekers in the UK Press, 19962005. Journal of English Linguistics, 3 (5), 5-38.

Hart, Christopher. 2010. Critical Discourse Analysis and Cognitive Science: New Perspectives on Immigration Discourse. Basingstoke: Palgrave Macmillan.

Islentyeva, Anna. 2018. The Undesirable Migrant in the British Press: Creating Bias Through Language. Neuphilologische Mitteilungen, 119 (2), 419-442.

Koller, Veronika. 2004. Metaphor and Gender in Business Media Discourse: A Critical Cognitive Study. Basingstoke: Palgrave.

Lee, David. 2008. Corpora and Discourse Analysis: New Ways of Doing Old Things. In Vijay Bhatia, John Flowerdew \& Rodney H. Jones (eds.) Advances in Discourse Studies. London \& New York: Routledge, 86-99.

Leonard, Richard L. \& Robert Taylor. 2016. The Routledge Guide to the European Union. London \& New York: Routledge.

McEnery, Tony \& Andrew Hardie. 2012. Corpus Linguistics: Method, Theory and Practice. Cambridge: Cambridge University Press.

McEnery, Tony \& Andrew Wilson. 2001. Corpus Linguistics. 2nd ed. Edinburgh: Edinburgh University Press.

Schuster, Liza. 2003. The Use and Abuse of Political Asylum in Britain and Germany. London: Frank Cass.

Sinclair, John. 1991. Corpus, Concordance, Collocation. Oxford: Oxford University Press.

Sinclair, John. 2004. Trust the Text: Language, Corpus and Discourse. London: Routledge.

Spiering, Menno. 2015. A Cultural History of British Euroscepticism. Basingstoke: Palgrave Macmillan.

Taylor, Charlotte. 2014. Investigating the Representation of Migrants in the UK and Italian Press: A Cross-Linguistic Corpus-Assisted Discourse Analysis. International Journal of Corpus Linguistics, 19 (3), 368-400.

Taylor, Charlotte \& Anna Marchi (eds.). 2018. Corpus Approaches to Discourse: A Critical Review. Oxon \& New York: Routledge.

Tognini-Bonelli, Elena. 2001. Corpus Linguistics at Work. Amsterdam: John Benjamins. van Dijk, Teun A. 1995. Aims of Critical Discourse Analysis. Japanese Discourses, 1 (1), $17-27$.

van Dijk, Teun A. 2015. Critical Discourse Analysis. In Deborah Schiffrin, Deborah Tannen \& Heidi E. Hamilton (eds.) The Handbook of Discourse Analysis. 2nd ed. London: Blackwell, 466-485. 


\section{References}

1 A lemma represents a group of words related to the same base differing only by inflection, e.g., refugee and refugees, refugee's and refugees' are all part of the noun lemma REFUGEE.

1 Years in parentheses beside Thatcher, Cameron, May, etc. indicate terms served as prime minister of the UK.

2 The number in parentheses indicates the absolute frequency of occurrence of the corresponding collocate.

1 The full editorial text is reproduced with the permission of Telegraph Media Group Limited (TMG).

2 The full text of the opinion piece is reproduced with the permission of Guardian News \& Media Limited (GNM).

Angermuller, Johannes, Dominique Maingueneau \& Ruth Wodak (eds.). 2014. The Discourse Studies Reader: Main Currents in Theory and Analysis. Philadelphia \& Amsterdam: John Benjamins.

Baker, Paul. 2006. Using Corpora in Discourse Analysis. London \& New York: Continuum. Bayley, Paul \& Geoffrey Williams (eds.). 2012. European Identity: What the Media Say. Oxford: Oxford University Press.

Blommaert, Jan. 2005. Discourse: A Critical Introduction. Cambridge: Cambridge University Press.

Brown, Gillian \& George Yule. 1983. Discourse Analysis. Cambridge: Cambridge University Press.

Butler, David \& Gareth Butler. 2000. Twentieth Century British Political Facts 1900-2000. 8th ed. Basingstoke: Macmillan Press.

Chilton, Paul. 2004. Analysing Political Discourse. London \& New York: Routledge.

Coleman, Stephen, Barry Griffiths \& Eleanor Simmons. 2002. Digital Jury - The Final Verdict. London: Hansard Society.

Conboy, Martin. 2011. Journalism in Britain: A Historical Introduction. Los Angeles: Sage. de Saussure, Ferdinand. (1916) 1959. Course in General Linguistics. Charles Bally (ed.). New York: Philosophical Library.

Fairclough, Norman. 1992. Discourse and Social Change. Cambridge: Polity Press.

Fairclough, Norman. 1995a. Critical Discourse Analysis. London: Longman.

Fairclough, Norman. 1995b. Media Discourse. London: Hodder Arnold.

Fairclough, Norman. 2010. Critical Discourse Analysis: The Critical Study of Language. Harlow, Munich: Longman.

Fairclough, Norman. 2015. Language and Power. 3rd ed. London \& New York: Routledge. Fairclough, Norman \& Ruth Wodak. 1997. Critical Discourse Analysis. In Teun van Dijk (ed.) Discourse as Social Interaction. London: Sage.

Foucault, Michel. 1971. L'ordre du Discours. Paris: Gallimard.

Foucault, Michel. 1972. The Archaeology of Knowledge and the Discourse on Language. New York: Pantheon Books.

Fowler, Roger. 1991. Language in the News: Discourse and Ideology in the Press. London: Routledge.

Fowler, Roger. 1996. On Critical Linguistics. In Rosa Caldas-Coulthard \& Malcolm Coulthard (eds.) Texts and Practices: Readings in Critical Discourse Analysis. London: Routledge.

Fowler, Roger, Robert Hodge, Gunter Kress \& Tony Trew. 1979. Language and Control. London: Routledge.

Gabrielatos, Costas \& Paul Baker. 2008. Fleeing, Sneaking, Flooding: A Corpus Analysis of Discursive Constructions of Refugees and Asylum Seekers in the UK Press 1996-2005. Journal of English Linguistics, 36 (1), 5-38. 
Gee, James Paul. 1999. An Introduction to Discourse Analysis: Theory and Method. London \& New York: Routledge.

Gumperz, John. 1982. Discourse Strategies. Cambridge: Cambridge University Press.

Halliday, Michael Alexander Kirkwood. 1978. Language as Social Semiotic. London: Edward Arnold.

Halliday, Michael Alexander Kirkwood. 1985. An Introduction to Functional Grammar. London: Edward Arnold.

Halliday, Michael Alexander Kirkwood. 2007. Language as Social Semiotic: Towards a General Sociolinguistic Theory. In Jonathan Webster (ed.) Michael Alexander Kirkwood Halliday, Language and Society. London: Continuum, 169-202.

Harris, Zellig S. 1952. Discourse Analysis. Language, 28, 1-30.

Hart, Christopher. 2010. Critical Discourse Analysis and Cognitive Science: New Perspectives on Immigration Discourse. Basingstoke: Palgrave Macmillan.

Kress, Gunther \& Theo van Leeuwen. 1996. Reading Images: The Grammar of Visual Design. London \& New York: Routledge.

Leavis, Queenie Dorothy. 1932. Fiction and Reading Public. London: Bellew.

Martin, James R. \& Ruth Wodak. 2003. Re/reading the Past: Critical and Functional Perspectives on Time and Value. Amsterdam \& Philadelphia: John Benjamins.

Richardson, John E. 2007. Analysing Newspapers: An Approach from Critical Discourse Analysis. London: Palgrave Macmillan.

Sinclair, John. 2004. Trust the Text: Language, Corpus and Discourse. London: Routledge.

Stubbs, Michael. 1983. Discourse Analysis: The Sociolinguistic Analysis of Natural Language. Chicago: Chicago University Press.

Taylor, Charlotte \& Anna Marchi (eds.). 2018. Corpus Approaches to Discourse: A Critical Review. Oxon \& New York: Routledge.

van Dijk, Teun A. 1991. Racism and the Press. London: Routledge.

van Dijk, Teun A. 1993. Principles of Critical Discourse Analysis. Discourse and Society, 4 (2), 249-283.

van Dijk, Teun A. 1995. Aims of Critical Discourse Analysis. Japanese Discourses, 1 (1), $17-27$.

van Dijk, Teun A. 1996. Discourse, Power and Access. In Rosa Caldas-Coulthard \& Malcolm Coulthard (eds.) Texts and Practices: Readings in Critical Discourse Analysis. London: Routledge, 84-104.

van Dijk, Teun A. 1998. Ideology: A Multidisciplinary Approach. London: Sage.

van Dijk, Teun A. 2001. Critical Discourse Analysis. In Deborah Schiffrin, Deborah Tannen \&

Heidi E. Hamilton (eds.) The Handbook of Discourse Analysis. London: Blackwell, 352-371.

van Dijk, Teun A. 2006. Ideology and Discourse Analysis. Journal of Political Ideologies, $1(2), 115-140$.

Widdowson, Henry G. 2000. On the Limitations of Linguistics Applied. Applied Linguistics, 21 (1), 3-25.

Widdowson, Henry G. 2004. Text, Context, and Pretext: Critical Issues in Discourse Analysis. Malden, MA: Blackwell.

Widdowson, Henry G. 2007. Discourse Analysis. Oxford: Oxford University Press.

Williams, Glyn. 1999. French Discourse Analysis: The Method of Post-Structuralism. London \& New York: Routledge.

Wodak, Ruth. 1996. Disorders of Discourse. London: Longman.

Wodak, Ruth. 2001. The Discourse-Historical Approach. In Ruth Wodak \& Michael Meyer (eds.) Methods of Critical Discourse Analysis. London: Sage, 1-13.

Aston, Guy \& Lou Burnard. 1998. The BNC Handbook: Exploring the British National Corpus with SARA. Edinburgh: Edinburgh University Press. 
Austin, John. 1962. How to Do Things with Words. Cambridge, MA: Harvard University Press. Baker, Mona, Gill Francis \& Elena Tognini-Bonelli (eds.). 1993. Text and Technology: In Honour of John Sinclair. Philadelphia \& Amsterdam: John Benjamins.

Baker, Paul. 2006. Using Corpora in Discourse Analysis. London \& New York: Continuum.

Baker, Paul. 2010. Sociolinguistics and Corpus Linguistics. Edinburgh: Edinburgh University Press.

Baker, Paul. 2017. American and British English: Divided by a Common Language? Cambridge: Cambridge University Press.

Baker, Paul, Costas Gabrielatos, Majid Khosravinik, Michal Krzyzanowski, Tony McEnery \& Ruth Wodak. 2008. A Useful Methodological Synergy? Combining Critical Discourse Analysis and Corpus Linguistics to Examine Discourses of Refugees and Asylum Seekers in the UK Press. Discourse and Society, 19 (3), 273-306.

Baker, Paul \& Tony McEnery (eds.). 2015. Corpora and Discourse: Integrating Discourse and Corpora. London: Palgrave Macmillan.

Biber, Douglas. 1993. Representativeness in Corpus Design. Literary and Linguistic Computing, 8 (4), 243-257.

Bloomfield, Leonard. 1933. Language. Chicago: University of Chicago Press.

Brezina, Vaclav, Tony McEnery \& Stephen Wattam. 2015. Collocations in Context: A New Perspective on Collocation Networks. International Journal of Corpus Linguistics, 20 (2), 139-173.

Butterfield, Jeremy. 2008. Damp Squid: The English Language Laid Bare. Oxford: Oxford University Press.

Charteris-Black, Jonathan. 2004. Corpus Approaches to Critical Metaphor Analysis. Basingstoke: Palgrave Macmillan.

Chomsky, Noam. 1957. Syntactic Structures. The Hague \& Paris: Mouton.

Chomsky, Noam. 1965. Aspects of the Theory of Syntax. Cambridge, MA: The MIT Press.

Davies, Mark. 2008. The Corpus of Contemporary American English: 450 Million Words, 1990-2012. Available at: corpus.byu.edu/coca.

Davies, Mark. 2010. The Corpus of Contemporary American English as the First Reliable Monitor Corpus of English. Literary and Linguistic Computing, 25 (4), 447-464.

de Saussure, Ferdinand. (1916) 1959. Course in General Linguistics. Charles Bally (ed.). New York: Philosophical Library.

Firth, John Rupert. 1957. Papers in Linguistics 1934-1951. London: Oxford University Press.

Firth, John Rupert. 1968. Selected Papers of J. R. Firth: 1952-59. Frank Palmer (ed.). London: Longman.

Francis, Gill. 1991. Nominal Group Heads and Clause Structure. Word, 42 (2), 144-156.

Francis, Nelson \& Henry Kučera. 1964. A Standard Corpus of Present-Day Edited American English. Providence: Brown University.

Gries, Stefan Thomas. 2008. Dispersions and Adjusted Frequencies in Corpora. International Journal of Corpus Linguistics, 13 (4), 403-437.

Gries, Stefan Thomas. 2013. 50-something Years of Work on Collocations: What Is or Should Be Next. International Journal of Corpus Linguistics, 18 (1), 137-166.

Gries, Stefan Thomas \& Anatol Stefanowitsch. 2004. Extending Collostructional Analysis: A Corpus-Based Perspective on 'Alternations'. International Journal of Corpus Linguistics, 9 (1), 97-129.

Halliday, Michael Alexander Kirkwood. 1966. Lexis as a Linguistic Level. In C. E. Bazell, J. C. Catford, M. A. K. Halliday \& R. H. Robins (eds.) In Memory of J. R. Firth. London: Longmans, $148-162$.

Halliday, Michael Alexander Kirkwood. 1994. An Introduction to Functional Grammar. 2nd ed. London: Edward Arnold. 
Hardie, Andrew \& Tony McEnery. 2010. On Two Traditions in Corpus Linguistics, and What They Have in Common. International Journal of Corpus Linguistics, 15 (3), 384-394.

Hunston, Susan. 2002. Corpora in Applied Linguistics. Cambridge: Cambridge University Press.

Leech, Geoffrey. 2013. Introducing Corpus Annotation. In Geoffrey Leech, Roger Garside \& Tony McEnery (eds.) Corpus Annotation: Linguistic Information from Computer Text Corpora. 2nd ed. London \& New York: Routledge.

Lew, Robert. 2009. The Web as Corpus Versus Traditional Corpora: Their Relative Utility for Linguists and Language Learners. In Paul Baker (ed.) Contemporary Corpus Linguistics. London \& New York: Continuum, 289-300.

Love, Robbie, Claire Dembry, Andrew Hardie, Vaclav Brezina \& Tony McEnery. 2017. The Spoken BNC2014: Designing and Building a Spoken Corpus of Everyday Conversations. International Journal of Corpus Linguistics, 22 (3), 319-344.

Marchi, Anna \& Charlotte Taylor. 2018. Introduction: Partiality and Reflexivity. In Charlotte Taylor \& Anna Marchi (eds.) Corpus Approaches to Discourse: A Critical Review. Oxon \& New York: Routledge.

McEnery, Tony \& Costas Gabrielatos. 2006. English Corpus Linguistics. In Bas Aarts \& April McMahon (eds.) The Handbook of English Linguistics. Oxford: Blackwell, 33-71.

McEnery, Tony \& Andrew Hardie. 2012. Corpus Linguistics: Method, Theory and Practice. Cambridge: Cambridge University Press.

McEnery, Tony \& Andrew Wilson. 2001. Corpus Linguistics. 2nd ed. Edinburgh: Edinburgh University Press.

McIntosh, Angus. 1961. Patterns and Ranges. Language, 37 (3), 325-37.

Oakes, Michael. 1998. Statistics for Corpus Linguistics. Edinburgh: Edinburgh University Press.

Partington, Alan. 2004. Corpora and Discourse, a Most Congruous Beast. In Alan Partington, John Morley \& Louann Haarman (eds.) Corpora and Discourse. Bern: Peter Lang, $11-20$.

Partington, Alan. 2006. Metaphors, Motifs and Similes Across Discourse Types: CorpusAssisted Discourse Studies (CADS) at Work. In Anatol Stefanowitsch \& Stefan Thomas Gries (eds.) Corpus-Based Approaches to Metaphor and Metonymy. Berlin \& New York: Mouton de Gruyter, 267-304.

Partington, Alan, Alison Duguid \& Charlotte Taylor. 2013. Patterns and Meanings in Discourse: Theory and Practice in Corpus-Assisted Discourse Studies (CADS). Amsterdam \& Philadelphia: John Benjamins.

Schmid, Helmut. 1994. Probabilistic Part-of-speech Tagging Using Decision Trees. Proceedings of International Conference on New Methods in Language Processing. Manchester, UK.

Searle, John. 1969. Speech Acts. Cambridge: Cambridge University Press.

Sinclair, John. 1966. Beginning the Study of Lexis. In C. E. Bazell, J. C. Catford, M. A. K. Halliday \& R. H. Robins (eds.) In Memory of J. R. Firth. London: Longmans, 410-430. Sinclair, John. 1991. Corpus, Concordance, Collocation. Oxford: Oxford University Press. Sinclair, John. 2003. Reading Concordances. London: Longman.

Sinclair, John. 2004. Trust the Text: Language, Corpus and Discourse. London: Routledge. Stefanowitsch, Anatol. 2006. Distinctive Collexeme Analysis and Diachrony: A Comment. Corpus Linguistics and Linguistic Theory, 2 (2), 257-262.

Stefanowitsch, Anatol \& Stefan Thomas Gries. 2003. Collostructions: Investigating the Interaction Between Words and Constructions. International Journal of Corpus Linguistics, 8 (2), 209-243. 
Stefanowitsch, Anatol \& Stefan Thomas Gries. 2005. Covarying Collexemes. Corpus Linguistics and Linguistic Theory, 1 (1), 1-46.

Stubbs, Michael. 1993. British Traditions in Text Analysis - From Firth to Sinclair. In Mona Baker, Gill Francis \& Elena Tognini-Bonelli (eds.) Text and Technology: In Honour of John Sinclair. Amsterdam \& Philadelphia: John Benjamins, 1-37.

Stubbs, Michael. 1996. Text and Corpus Analysis. London: Blackwell.

Taylor, Charlotte. 2013. Searching for Similarity Using Corpus-Assisted Discourse Studies. Corpora, 8 (1), 81-113.

Taylor, Charlotte. 2018. Similarity. In Charlotte Taylor \& Anna Marchi (eds.) Corpus Approaches to Discourse: A Critical Review. Oxon \& New York: Routledge.

Taylor, Charlotte \& Anna Marchi (eds.). 2018. Corpus Approaches to Discourse: A Critical Review. Oxon \& New York: Routledge.

Tognini-Bonelli, Elena. 2001. Corpus Linguistics at Work. Amsterdam: John Benjamins.

Baker, Paul. 2006. Using Corpora in Discourse Analysis. London \& New York: Continuum.

Baker, Paul. 2007. Discourses of Refugees and Asylum Seekers in the UK Press, 19962006: Full Research Report. ESRC End of Award Report, RES-000-22-1381. Swindon: ESRC.

Baker, Paul, Costas Gabrielatos, Majid Khosravinik, Michal Krzyzanowski, Tony McEnery \& Ruth Wodak. 2008. A Useful Methodological Synergy? Combining Critical Discourse Analysis and Corpus Linguistics to Examine Discourses of Refugees and Asylum Seekers in the UK Press. Discourse and Society, 19 (3), 273-306.

Baker, Paul \& Tony McEnery. 2005. A Corpus-based Approach to Discourses of Refugees and Asylum Seekers in UN and Newspaper Texts. Journal of Language and Politics, 4 (2), 197-226.

Charteris-Black, Jonathan. 2006. Britain as a Container: Immigration Metaphors in the 2005 Election Campaign. Discourse and Society, 17 (6), 563-582.

Flach, Susanne. 2015. Online Tutorial. Korpuslinguistik Mit CQP. Berlin. Available at: http://userpage.fu-berlin.de/ flach/corpling/cqp/ (Accessed 18 April 2019).

Flach, Susanne. 2017. Collostructions: An R Implementation for the Family of Collostructional Methods. R Package Version 0.1.0. Berlin.

Fowler, Roger. 1991. Language in the News: Discourse and Ideology in the Press. London: Routledge.

Gabrielatos, Costas \& Paul Baker. 2008. Fleeing, Sneaking, Flooding: A Corpus Analysis of Discursive Constructions of Refugees and Asylum Seekers in the UK Press, 19962005. Journal of English Linguistics, 3 (5), 5-38.

Gries, Stefan Thomas \& Anatol Stefanowitsch. 2004. Extending Collostructional Analysis: A Corpus-Based Perspective on 'Alternations'. International Journal of Corpus Linguistics, 9 (1), 97-129.

Hart, Christopher. 2010. Critical Discourse Analysis and Cognitive Science: New Perspectives on Immigration Discourse. Basingstoke: Palgrave Macmillan.

Hart, Christopher. 2014. Discourse, Grammar and Ideology: Functional and Cognitive Perspectives. London: Bloomsbury.

Hoey, Michael. 2005. Lexical Priming: A New Theory of Words and Language. London: Routledge.

Islentyeva, Anna. 2018. The Undesirable Migrant in the British Press: Creating Bias Through Language. Neuphilologische Mitteilungen, 119 (2), 419-442.

Leonard, Richard L. \& Robert Taylor. 2016. The Routledge Guide to the European Union. London \& New York: Routledge. 
Musolff, Andreas. 2015. Dehumanizing Metaphors in UK Immigrant Debates in Press and Online Media. Journal of Language Aggression and Conflict, 3 (1), 41-56.

Oakes, Michael. 1998. Statistics for Corpus Linguistics. Edinburgh: Edinburgh University Press.

Stubbs, Michael. 1995. Collocations and Semantic Profiles: On the Cause of the Trouble with Quantitative Studies. Functions of Language, 2 (1), 23-55.

Stubbs, Michael. 1996. Text and Corpus Analysis. London: Blackwell.

Stubbs, Michael. 2001. Words and Phrases: Corpus Studies of Lexical Semantics. Oxford: Blackwell.

Taylor, Charlotte. 2014. Investigating the Representation of Migrants in the UK and Italian Press: A Cross-Linguistic Corpus-assisted Discourse Analysis. International Journal of Corpus Linguistics, 19 (3), 368-400.

van Dijk, Teun A. 1991. Racism and the Press. London: Routledge.

van Dijk, Teun A. 1996. Discourse, Power and Access. In Rosa Caldas-Coulthard \& Malcolm Coulthard (eds.) Texts and Practices: Readings in Critical Discourse Analysis. London: Routledge, 84-104.

van Leeuwen, Theo. 1996. The Representation of Social Actors. In Rosa CaldasCoulthard \& Malcolm Coulthard (eds.) Texts and Practices: Readings in Critical Discourse Analysis. London: Routledge, 32-70.

Pre-Referendum Corpus of Newspaper Articles on Immigration and Asylum Seeking. 2019. Islentyeva, Anna \& Anatol Stefanowitsch. Department of English Language and Literature. Free University of Berlin.

Baker, Paul. 2006. Using Corpora in Discourse Analysis. London \& New York: Continuum.

Baker, Paul, Costas Gabrielatos, Majid Khosravinik, Michal Krzyzanowski, Tony McEnery \& Ruth Wodak. 2008. A Useful Methodological Synergy? Combining Critical Discourse Analysis and Corpus Linguistics to Examine Discourses of Refugees and Asylum Seekers in the UK Press. Discourse and Society, 19 (3), 273-306.

Charteris-Black, Jonathan. 2006. Britain as a Container: Immigration Metaphors in the 2005 Election Campaign. Discourse and Society, 17 (6), 563-582.

EU Referendum Results. 2016. BBC News. Available at: www.bbc.com/news/politics/ eu_referendum/results (Accessed 10 April 2020).

Flach, Susanne. 2017. Collostructions: An R Implementation for the Family of Collostructional Methods. R Package Version 0.0.7. Berlin.

Gifford, Chris. 2017. The Making of Eurosceptic Britain. London \& New York: Routledge.

Gries, Stefan Thomas \& Anatol Stefanowitsch. 2004. Extending Collostructional Analysis: A Corpus-Based Perspective on 'Alternations'. International Journal of Corpus Linguistics, 9 (1), 97-129.

Hoey, Michael. 2005. Lexical Priming: A New Theory of Words and Language. London: Routledge.

Islentyeva, Anna. 2018. The Undesirable Migrant in the British Press: Creating Bias Through Language. Neuphilologische Mitteilungen, 119 (2), 419-442.

Koller, Veronika, Susanne Kopf \& Marlene Miglbauer (eds.). 2019. Discourses of Brexit. London \& New York: Routledge.

LabourParty Manifesto. 1983.Availableat:www.labour-party.org.uk/manifestos/1983/1983labour manifesto.shtml (Accessed 10 April 2020).

Leonard, Richard L. \& Robert Taylor. 2016. The Routledge Guide to the European Union. London \& New York: Routledge. 
Oakes, Michael. 1998. Statistics for Corpus Linguistics. Edinburgh: Edinburgh University Press.

Saunders, Robert. 2016. A Tale of Two Referendums: 1975 and, 2016. Political Quarterly, 87 (3), 318-322.

Spiering, Menno. 2004. British Euroscepticism. European Studies, 20 (1), 127-149.

Spiering, Menno. 2015. A Cultural History of British Euroscepticism. Basingstoke: Palgrave Macmillan.

Post-Referendum Corpus of Newspaper Articles on Immigration and Asylum Seeking. 2019. Islentyeva, Anna, Anatol Stefanowitsch, Mihera Abdel Kafi, Torben Scheffler \& Willi Werner. Department of English Language and Literature. Free University of Berlin.

Pre-Referendum Corpus of Newspaper Articles on Immigration and Asylum Seeking. 2019. Islentyeva, Anna \& Anatol Stefanowitsch. Department of English Language and Literature. Free University of Berlin.

Baker, Paul. 2006. Using Corpora in Discourse Analysis. London \& New York: Continuum. Baker, Paul, Costas Gabrielatos, Majid Khosravinik, Michal Krzyzanowski, Tony McEnery \& Ruth Wodak. 2008. A Useful Methodological Synergy? Combining Critical Discourse Analysis and Corpus Linguistics to Examine Discourses of Refugees and Asylum Seekers in the UK Press. Discourse and Society, 19 (3), 273-306.

Bayley, Paul \& Geoffrey Williams (eds.). 2012. European Identity: What the Media Say. Oxford: Oxford University Press.

Charteris-Black, Jonathan. 2006. Britain as a Container: Immigration Metaphors in the 2005 Election Campaign. Discourse and Society, 17 (6), 563-582.

Chilton, Paul. 2004. Analysing Political Discourse. London \& New York: Routledge.

Fletcher, Charles Robert Leslie \& Rudyard Kipling. 1911. A History of England. Oxford \& London: Clarendon Press.

Fussell, Paul. 1977. The Great War and Modern Memory. Oxford: Oxford University Press. Hart, Christopher. 2010. Critical Discourse Analysis and Cognitive Science: New Perspectives on Immigration Discourse. Basingstoke: Palgrave Macmillan.

Hoey, Michael. 2005. Lexical Priming: A New Theory of Words and Language. London: Routledge.

Islentyeva, Anna. 2018. The Undesirable Migrant in the British Press: Creating Bias Through Language. Neuphilologische Mitteilungen, 119 (2), 419-442.

Keegan, John. 1997. England Is a Garden. The Late Sir John Keegan on the Peculiarly English Sense of Belonging Created by the War Graves Commission. Available at: www. prospectmagazine.co.uk/magazine/englandisagarden (Accessed 1 April 2020).

Kipling, Rudyard. 2000. Selected Poems. Peter Keating (ed.). London: Penguin Classics.

Lassen, Inger, Jeanne Strunck \& Torben Vestergaard (eds.). 2006. Mediating Ideology in Text and Image: Ten Critical Studies. Amsterdam \& Philadelphia: John Benjamins.

MacFarlane, Don. 2011. The Western Isles. Available at: https://westernisles.wordpress. com/emigration/ (Accessed 1 June 2020).

Musolff, Andreas. 2015. Dehumanizing Metaphors in UK Immigrant Debates in Press and Online Media. Journal of Language Aggression and Conflict, 3 (1), 41-56.

Santa Ana, Otto. 1999. 'Like an Animal I Was Treated': Anti-immigrant Metaphor in US Public Discourse. Discourse \& Society, 10 (2), 191-224.

Spiering, Menno. 2015. A Cultural History of British Euroscepticism. Basingstoke: Palgrave Macmillan.

Stubbs, Michael. 1995. Collocations and Semantic Profiles: On the Cause of the Trouble with Quantitative Studies. Functions of Language, 2 (1), 23-55.

Stubbs, Michael. 1996. Text and Corpus Analysis. London: Blackwell. 
Stubbs, Michael. 2001. Words and Phrases: Corpus Studies of Lexical Semantics. Oxford: Blackwell.

Taylor, Charlotte. 2014. Investigating the Representation of Migrants in the UK and Italian Press: A Cross-Linguistic Corpus-assisted Discourse Analysis. International Journal of Corpus Linguistics, 19 (3), 368-400.

Taylor, Charlotte. 2020. Representing the Windrush Generation: Metaphor in Discourses Then and Now. Critical Discourse Studies, 17 (1), 1-21.

British National Corpus (BNC 1994). XML Edition. 2007. Oxford: University of Oxford Text Archive. Available at: http://purl.ox.ac.uk/ota/2554.

American Heritage Dictionary of the English Language. Available at: ahdictionary.com.

Cambridge Idioms Dictionary. Available at: itools.com/tool/cambridge-internationaldictionary-of-idioms.

Charteris-Black, Jonathan. 2004. Corpus Approaches to Critical Metaphor Analysis. Basingstoke: Palgrave Macmillan.

Hobbes, Thomas. (1651) 2012. Leviathan. Noel Malcolm (ed.). Oxford: University Press.

Lakoff, George \& Mark Johnson. 1980. Metaphors We Live by. Chicago: University of Chicago Press.

Longman Dictionary of Contemporary English. Available at: www.ldoceonline.com.

Louw, Bill. 1993. Irony in the Text or Insincerity in the Writer? The Diagnostic Potential of Semantic Prosodies. In Mona Baker, Gill Francis \& Elena Tognini-Bonelli (eds.) Text and Technology: In Honour of John Sinclair. Amsterdam: John Benjamins, 157-176.

Macmillan Dictionary. Available at: www.macmillandictionary.com.

McEnery, Tony \& Andrew Hardie. 2012. Corpus Linguistics: Method, Theory and Practice. Cambridge: Cambridge University Press.

Partington, Alan, Alison Duguid \& Charlotte Taylor. 2013. Patterns and Meanings in Discourse: Theory and Practice in Corpus-Assisted Discourse Studies (CADS). Amsterdam \& Philadelphia: John Benjamins.

Semino, Elena, Zsófia Demjén, Andrew Hardie, Sheila Payne \& Paul Rayson. 2018 Metaphor, Cancer and the End of Life: A Corpus-based Study. London \& New York: Routledge.

Sinclair, John. 2003. Reading Concordances. London: Longman.

Sinclair, John. 2004. Trust the Text: Language, Corpus and Discourse. London: Routledge. Stefanowitsch, Anatol. 2006. Corpus-Based Approaches to Metaphor and Metonymy. In Anatol Stefanowitsch \& Stefan Thomas Gries (eds.) Corpus-Based Approaches to Metaphor and Metonymy. Berlin \& New York: Mouton de Gruyter, 1-16.

Stubbs, Michael. 1995. Collocations and Semantic Profiles: On the Cause of the Trouble with Quantitative Studies. Functions of Language, 2 (1), $23-55$.

Stubbs, Michael. 2001. Words and Phrases: Corpus Studies of Lexical Semantics. Oxford: Blackwell.

Tognini-Bonelli, Elena. 1996. Corpus Theory and Practice. New York: The Words Collective. British National Corpus (BNC 1994). XML Edition. 2007. Oxford: University of Oxford Text Archive. Available at: http://purl.ox.ac.uk/ota/2554.

The Brown Corpus of American English (Brown). 1979. Francis, W. Nelson \& Henry Kučera. Providence, Rhode Island, Department of Linguistics. Brown University. Available at: clu.uni.no/icame/manuals/brown/index.htm

Corpus of Contemporary American English (COCA). 2008. Davies, Mark. The Corpus of Contemporary American English: 450 Million Words, 1990-2012. Available at: corpus. byu.edu/coca 
Lancaster - Oslo - Bergen Corpus (LOB). 1981-1986. Leech, Geoffrey, Roger Garside, Stig Johansson \& Knut Hofland. Lancaster University, University of Oslo, Norwegian Centre for the Humanities at Bergen.

Pre-Referendum Corpus of Newspaper Articles on Immigration and Asylum Seeking. 2019. Islentyeva, Anna \& Anatol Stefanowitsch. Department of English Language and Literature. Free University of Berlin.

Baker, Paul. 2006. Using Corpora in Discourse Analysis. London \& New York: Continuum. Bayley, Paul \& Geoffrey Williams (eds.). 2012. European Identity: What the Media Say. Oxford: Oxford University Press.

Byrne, Chris, Nick Randall \& Kevin Theakston. 2017. Evaluating British Prime Ministerial Performance: David Cameron's Premiership in Political Time. British Journal of Politics and International Relations, 19 (1), 202-220.

Charteris-Black, Jonathan. 2006. Britain as a Container: Immigration Metaphors in the 2005 Election Campaign. Discourse and Society, 17 (6), 563-582.

Fowler, Roger. 1991. Language in the News: Discourse and Ideology in the Press. London: Routledge.

Gries, Stefan Thomas \& Anatol Stefanowitsch. 2004. Extending Collostructional Analysis: A Corpus-Based Perspective on 'Alternations'. International Journal of Corpus Linguistics, 9 (1), 97-129.

Hart, Christopher. 2010. Critical Discourse Analysis and Cognitive Science: New Perspectives on Immigration Discourse. Basingstoke: Palgrave Macmillan.

Hart, Christopher. 2014. Discourse, Grammar and Ideology: Functional and Cognitive Perspectives. London: Bloomsbury.

Inglehart, Ronald \& Pippa Norris. 2016. Trump, Brexit, and the Rise of Populism: Economic Have-Nots and Cultural Backlash. HKS Working Paper No. RWP16-026.

Islentyeva, Anna. 2019. The Europe of Scary Metaphors: The Voices of the British Right-Wing Press. Zeitschrift für Anglistik und Amerikanistik, 67 (3), 209-229.

Koller, Veronika. 2004. Businesswomen and War Metaphors: Possessive, Jealous and Pugnacious? Journal of Sociolinguistics, 8 (1), 3-22.

Lassen, Inger, Jeanne Strunck \& Torben Vestergaard (eds.). 2006. Mediating Ideology in Text and Image: Ten Critical Studies. Amsterdam \& Philadelphia: John Benjamins.

Mudde, Cas. 2004. The Populist Zeitgeist. Government and Opposition, 39 (4), 541-563.

Mudde, Cas. 2007. Populist Radical Right Parties in Europe. Cambridge: Cambridge University Press.

Musolff, Andreas. 2015. Dehumanizing Metaphors in UK Immigrant Debates in Press and Online Media. Journal of Language Aggression and Conflict, 3 (1), 41-56.

Stefanowitsch, Anatol. 2006. Corpus-based Approaches to Metaphor and Metonymy. In Anatol Stefanowitsch \& Stefan Thomas Gries (eds.) Corpus-Based Approaches to Metaphor and Metonymy. Berlin \& New York: De Gruyter.

Stefanowitsch, Anatol. 2019. Delivering a Brexit Deal to the British People: Theresa May as a Reluctant Populist. Zeitschrift für Anglistik und Amerikanistik, 67 (3), 231-263.

Street, John. 2011. Mass Media, Politics and Democracy. 2nd ed. Basingstoke: Palgrave Macmillan.

Stubbs, Michael. 1993. British Traditions in Text Analysis - From Firth to Sinclair. In Mona Baker, Gill Francis \& Elena Tognini-Bonelli (eds.) Text and Technology: In Honour of John Sinclair. Philadelphia: John Benjamins, 1-37.

Taylor, Charlotte. 2014. Investigating the Representation of Migrants in the UK and Italian Press: A Cross-Linguistic Corpus-assisted Discourse Analysis. International Journal of Corpus Linguistics, 19 (3), 368-400. 
van Dijk, Teun A. 1996. Discourse, Power and Access. In Rosa Caldas-Coulthard \& Malcolm Coulthard (eds.) Texts and Practices: Readings in Critical Discourse Analysis. London: Routledge, 84-104.

van Leeuwen, Theo. 1996. The Representation of Social Actors. In Rosa Caldas-Coulthard \& Malcolm Coulthard (eds.) Texts and Practices: Readings in Critical Discourse Analysis. London: Routledge, 32-70.

Wodak, Ruth. 2016. "We Have the Character of an Island Nation": A Discourse-Historical Analysis of David Cameron's "Bloomberg Speech" on the European Union. European University Institute Working Paper, 2016 (36). 